\title{
Vestibular da Unicamp: uma proposta dialógica de redação
}

\section{Unicamp college entrance exame: a dialogic proposal for composition}

Lucas Vinício de Carvalho Maciel*

UNICAMP

RESUMO: Neste artigo, analiso uma dissertação do vestibular da Unicamp, a partir da concepção de "dialogismo" proposta pelos membros do Círculo de Bakhtin. Procuro demonstrar como essa redação pode ser tomada como exemplo dos aspectos dialógicos que regem a linguagem.

PALAVRAS-CHAVE: dialogismo, gênero discursivo, Bakhtin, redação.

ABSTRACT: In this paper, I analyze a Unicamp college entrance exam composition by means of the notion of dialogism proposed by Bakhtin's Circle members. My aim is to show how this composition is able to point the language dialogic aspects. KEYWORDS: dialogism, discursive genre, Bakhtin, composition.

"Ser significa comunicar-se pelo diálogo. Quando termina o diálogo, tudo termina."

(BAKHTIN, 1929/1963, p. 257.)

\section{Introdução}

Tendo como premissa a discussão sobre o dialogismo proposta pelos integrantes do Círculo de Bakhtin, examino, neste artigo, uma redação do vestibular da Unicamp, que, espero, sirva como exemplo de uma enunciação dialógica.

Primeiramente, procuro mostrar sucintamente como é colocada a problemática do dialogismo no Círculo de Bakhtin, destacando a importância do conceito de gênero do discurso para a compreensão desta questão. Isso porque nos elementos constituintes do gênero discursivo - conteúdo

*lucasvcmaciel@yahoo.com.br 
temático, estrutura composicional e estilo - é possível perceber o dialogismo de maneira bastante clara, por meio de marcas que evidenciam o gênero como um elo na comunicação humana.

A partir, então, de nosso entendimento do dialogismo, seguimos analisando a redação do vestibular, procurando expor como essa redação é um exemplo das relações dialógicas estabelecidas entre os enunciados, na medida em que o texto do vestibulando responde de maneira dialógica à proposta da prova do vestibular e traz em sua concretização vozes alheias.

\section{A ideia de dialogismo no Círculo de Bakhtin}

No início do século 20, mais especificamente de 1919 a 1929, pensadores russos, entre os quais Mikhail Bakhtin, Valentin Voloshinov e Pavel Medvedev, costumavam se reunir para debater questões filosóficas, literárias e linguísticas. A posteriori, a crítica adotou a denominação de "Círculo de Bakhtin" para se referir a esse grupo, que nos deixou importante legado de suas discussões. A denominação, em que se destaca a figura de Bakhtin, justificase pela importância de suas reflexões frente à assembleia de amigos.

Das diversas questôes suscitadas no interior do "Círculo", provavelmente a que mais provocou reflexôes no campo dos estudos da linguagem, até mesmo porque conduz a uma nova forma de se enxergar os enunciados, é aquela que versa sobre o "dialogismo". Passemos a voz a Bakhtin (1929/1963, p. 42), para que ele nos inicie nessa matéria:

As relações dialógicas - fenômeno bem mais amplo do que as relações entre as réplicas do diálogo expresso composicionalmente - são um fenômeno quase universal, que penetra toda a linguagem humana e todas as relações e as manifestações da vida humana, em suma, tudo que tem sentido e importância.

O dialogismo, fenômeno que "penetra toda a linguagem humana", seria a relação de "diálogo" entre os diversos enunciados. A exemplo de um diálogo, em que uma fala responde à outra, um enunciado (um texto qualquer, uma carta, uma propaganda, etc.) sempre "dialoga" com outros enunciados, seja "respondendo" aos enunciados precedentes, seja esperando as possíveis respostas futuras. É como se cada enunciado fosse uma fala num diálogo: essa fala responde a vozes anteriores e também poderá ser respondida, posteriormente, por outras vozes. 
Para entender melhor a ideia de "resposta" de um enunciado aos enunciados precedentes, precisamos ter claro que, ao enunciar, todo falante pressupóe a existência de "enunciados antecedentes - dos seus e alheios - com os quais seu enunciado entra nessas ou naquelas relações (baseia-se neles, polemiza com eles, simplesmente os pressupõe já conhecidos do ouvinte)" (BAKHTIN, [1952-1953], p. 272). Quando escrevo, por exemplo, ainda que implicitamente, necessariamente me reporto a enunciados precedentes com os quais concordo, discordo ou, enfim, suponho, de alguma forma, já conhecidos pelo leitor a quem me dirijo. Também, quando falo, sempre considero enunciados anteriores, pois nunca enuncio algo, radicalmente, novo. Como diria Bakhtin (op. cit., p. 272), o falante não é "o primeiro a ter violado o eterno silêncio do universo", ninguém é o mítico Adão, pronunciando a palavra pela primeira vez. Qualquer enunciado sempre retoma, de uma forma ou de outra, enunciados anteriores.

Qualquer texto sempre retoma palavras alheias. Isso, por exemplo, é evidente nos textos acadêmicos em que o enunciado está sempre perpassado por vozes alheias. No caso do texto acadêmico, essas vozes, em geral, aparecem nitidamente marcadas pelas citações e referências bibliográficas. Entretanto, mesmo numa fala cotidiana, nosso enunciado está repleto de palavras alheias. Até mesmo uma banal conversa acerca do aumento do preço do pão na padaria de nosso bairro está prenhe de enunciados precedentes. Podemos nos reportar às notícias veiculadas em jornais - televisivos, impressos ou digitais - acerca do aumento do preço da farinha. Também podemos nos reportar à fala de nosso vizinho que assegura que esse aumento vem do projeto do dono da padaria de angariar dinheiro para uma futura reforma em seu estabelecimento comercial, por exemplo. Em qualquer caso, estamos nos reportando a vozes que nos precedem.

Além de retomarmos vozes precedentes, quando enunciamos, também esperamos sempre uma resposta daquele (ou daqueles) a quem nos dirigimos. Ao enunciar, o sujeito "não espera uma compreensão passiva, por assim dizer, que apenas duble o seu pensamento em voz alheia, mas uma resposta, uma concordância, uma participação, uma execução, etc." (BAKHTIN, [19521953], p. 272). Falamos como falamos, pois sabemos que seremos (ou, pelo menos, pretendemos ser) compreendidos desta ou daquela forma. O enunciado também se constitui nas relações dialógicas com os enunciados futuros que poderá suscitar.

O dialogismo, portanto, é a relação - a exemplo de um diálogo - que um enunciado mantém com outros enunciados, precedentes e futuros, que o 
cercam. Retomando vozes precedentes e lançando-se a respostas futuras, concretizadas em outros enunciados. Desse modo, o dialogismo se mantém pela contínua retomada de um enunciado por outro.

\section{O gênero discursivo e os três elementos constitutivos do enunciado}

Para os integrantes do Círculo de Bakhtin, o enunciado e seus elementos constituintes só podem ser compreendidos de um modo mais amplo, quando se considera a complexa teia dialógica em que o enunciado se encontra. Os elementos do enunciado são abordados em obras de Voloshinov e de Medvedev, mas Bakhtin é quem os estudará com mais profundidade. Segundo o intelectual russo (BAKHTIN, op. cit., p. 261-262):

O emprego da língua efetua-se em forma de enunciados (orais ou escritos) concretos e únicos, proferidos pelos integrantes desse ou daquele campo da atividade humana. Esses enunciados refletem as condições específicas e as finalidades de cada referido campo não só por seu conteúdo (temático) e pelo estilo da linguagem, (...) mas, acima de tudo, por sua construção composicional. Todos esses três elementos - o conteúdo temático, o estilo, a construção composicional - estão indissoluvelmente ligados no todo do enunciado e são igualmente determinados pela especificidade de um determinado campo da comunicação. Evidentemente, cada enunciado particular é individual, mas cada campo de utilização da linguagem elabora seus tipos relativamente estáveis de enunciados, os quais denominamos gêneros do discurso.

Bakhtin, portanto, postula a existência de três elementos constitutivos do enunciado: conteúdo temático, construção composicional e estilo. Além disso, destaca que os "tipos relativamente estáveis de enunciados" são denominados "gêneros do discurso". Se esses três elementos constituem o enunciado e o enunciado deve ser tomado em suas relações dialógicas, logo esses três elementos também devem ser entendidos em suas relações dialógicas. É necessário observar como cada constituinte do enunciado se comporta em relação ao dialogismo que perpassa (necessária e inescapavelmente) todo enunciado. Precisamos compreender como o tema, a composição e o estilo se constituem nas relações dialógicas que permeiam os gêneros. Ou seja, ver o tema como o tema no dialogismo, a construção composicional como a construção composicional no dialogismo e, por fim, o estilo como estilo no dialogismo. 
Dessa perspectiva, assumimos que o tema do enunciado sempre está ligado a enunciados precedentes com os quais dialoga, pois, quando falamos sobre algo, consideramos o que já foi dito sobre esse assunto. Segundo Bakhtin (1924-1993, p. 86):

(...) todo o discurso concreto (enunciação) encontra aquele objeto para o qual está voltado sempre, por assim dizer, já desacreditado, contestado, avaliado, envolvido por uma névoa escura ou, pelo contrário, iluminado pelos discursos de outrem que já falaram sobre ele.

Ou seja, quando discorremos sobre um tema, consideramos as diversas opiniōes (favoráveis ou contrárias) que conhecemos a respeito dele, levamos em conta o que já foi dito sobre esse tema. Essas opiniōes não nos são indiferentes. Aquilo que lemos ou ouvimos acerca dele influencia nossa forma de enunciar. O tema de nossa enunciação sempre está marcado pelos "discursos de outrem que já falaram sobre ele”. Quando alguém fala ou escreve, está retomando ideias e pensamentos de outros (ou dele mesmo), está retomando "vozes" precedentes. Um texto ou um discurso, desde uma fala corriqueira até o anúncio de uma descoberta científica, jamais é "inédito" - no sentido mais radical do termo -, ninguém é o primeiro a enunciar. Basta pensar, por exemplo, que mesmo no anúncio da descoberta científica, o pesquisador se reporta a conceitos conhecidos pelos seus interlocutores.

Além da utilização de vozes alheias na formulação de seu enunciado próprio, todo falante realiza sua enunciação, aguardando as réplicas que suscitará. Sua voz, que respondeu à de alguém, poderá, agora, servir para as respostas alheias, futuras. Mesmo numa situação cotidiana da vida, por exemplo, quando comentamos com nosso amigo a derrota de nosso time, não apenas lhe comunicamos esse fato. Esperamos sua resposta: desejamos que também nos acompanhe em nossa revolta contra a má arbitragem (a nosso ver), que compartilhe conosco o sentimento de desilusão frente ao título perdido. Não falamos por falar, falamos para sermos entendidos e aceitos; por isso falamos de determinado modo e não de outro. Mesmo nesse contexto digamos - prosaico, importa-nos a opiniāo de nosso interlocutor acerca de nós, ou seja, acerca do que afirmamos. A avaliação de nosso interlocutor nos guia o tempo todo em nossa enunciação. $\mathrm{O}$ nosso enunciado se faz na expectativa da réplica futura.

Do mesmo modo que o tema, os aspectos composicionais só podem ser compreendidos de uma maneira mais acurada se os entendemos nas relaçóes 
dialógicas que os enunciados mantêm entre si. Segundo Voloshinov, o "tema e a forma (...) estão indissoluvelmente ligados" já que "são as mesmas forças e as mesmas condições que dão vida a ambos" (BAKHTIN/VOLOSHINOV, 1929, p. 47). Como estão unidos, é incoerente acreditar que as condições enunciativas alcancem apenas o tema, sem igualmente se refletir na forma. Ao enunciar, o sujeito retoma determinadas construções composicionais e espera respostas, que também virão sob determinadas formas de enunciado. $O$ gênero se mantém precisamente, porque, ao formular um novo enunciado, o falante recorre às estruturas composicionais que conhece daquele gênero em que pretende concretizar sua enunciação. Além disso, outro, no futuro, poderá recorrer a uma enunciação atual a fim de buscar nela bases para a composição estrutural de seu enunciado. A forma, como parte do enunciado, tem um passado, um presente e um futuro que permitem a manutenção histórica dos gêneros, pela retomada dialógica das estruturas de composição.

Na passagem abaixo, Bakhtin (1929/1963, p. 106, grifo do autor) comenta o caráter histórico dos gêneros literários, mas creio que é possível assumir que todos os gêneros têm a sua historicidade:

Por sua natureza mesma, o gênero literário reflete as tendências mais estáveis, "perenes" da evolução da literatura. O gênero sempre conserva os elementos imorredouros da archaica. (...) O gênero vive do presente mas sempre recorda seu passado, o seu começo. É o representante da memória criativa no processo de desenvolvimento literário. É precisamente por isto que tem a capacidade de assegurar a unidade e a continuidade desse desenvolvimento.

Entre os elementos perenes do gênero, é possível supor que os aspectos composicionais têm grande peso, pois, conforme Bakhtin ([1952-1953], p. 261), os gêneros são definidos "acima de tudo, por sua construção composicional". Caso não houvesse essa historicidade - pelo menos, alguma perenidade na forma - a comunicação seria impraticável, pois o sujeito teria que reinventar os gêneros a cada nova enunciação.

"Se os gêneros do discurso não existissem e se nós não os dominássemos, se tivéssemos de criá-los pela primeira vez no processo do discurso, de construir livremente e pela primeira vez cada enunciado, a comunicação discursiva seria quase impossível" (BAKHTIN, [1952-1953], p. 283).

O sujeito, ao enunciar por meio de um gênero, vale-se de sua construção composicional típica, já que os "gêneros do discurso (...) para o indivíduo falante (...) têm significado normativo, não são criados por ele mas dados a ele" 
(BAKHTIN, [1952-1953], p. 285). O caráter normativo, que o mantém relativamente estável durante o decorrer do tempo, deve-se ao dialogismo, já que essa manutenção depende da retomada das formas composicionais estabilizadas. Assim, a composição do enunciado deve ser compreendida nas relações dialógicas que o enunciado mantém, retomando enunciados anteriores e prestando-se no futuro como base a novas enunciações. O dialogismo é que possibilita a manutenção da composição característica dos gêneros.

Como os demais elementos do gênero, o estilo só pode ser estudado ao se levar em conta que seu funcionamento é regulado pelas relações dialógicas. O estilo de um enunciado é um e não outro, porque seu autor considera, em sua enunciação, estes ou aqueles enunciados precedentes e porque pretende suscitar certas respostas. Segundo Bakhtin: "sem levar em conta a relação do falante com o outro e seus enunciados (presentes e antecipáveis), é impossível compreender o gênero ou estilo do discurso" ([1952-1953], p. 304, grifo do autor).

Isso porque, conforme lembra Voloshinov, "por sua estrutura semântica e estilística, eles [os enunciados] são de fato essencialmente dialógicos (...) [pois] todo enunciado (discurso, conferência, etc.) é concebido em função de um ouvinte, ou seja, de sua compreensão e de sua resposta"' (VOLOSHINOV, 1930 , p. 292, tradução nossa). É em função dos seus parceiros de interlocução que todo enunciado é arquitetado, inclusive em termos das escolhas estilísticas. Os integrantes do Círculo de Bakhtin não negam totalmente a tradicional visão do estilo como escolhas que singularizam o enunciado de um determinado sujeito, mas destacam que as escolhas não obedecem apenas às vontades do autor, pois estão subordinadas à situação de enunciação e são influenciadas pelos enunciados com os quais o falante se relaciona.

O estilo compreende organicamente em si as indicações externas, a correlação de seus elementos próprios com aqueles do contexto de outrem. A política interna do estilo (combinação dos elementos) determina sua política exterior (em relação ao discurso de outrem). O discurso como que vive na fronteira de seu próprio contexto e daquele de outrem. (BAKHTIN, 1934-1935, p. 92).

\footnotetext{
${ }^{1}$ (...)par leur structure sémantique et stylistique, ils [os enunciados] sont en fait essentiellement dialoguiques (...) [pois] "tout énoncé (discours, conference, etc.) est conçu en function d'un auditeur, c'est-à-dire de sa compréhension et de sa réponse.
} 
O estilo, portanto, como elemento constitutivo do gênero deve ser observado no interior de suas relações dialógicas. O sujeito é relativamente livre para selecionar os recursos linguísticos com os quais formulará seu enunciado, mas o falante opta por este ou aquele modo de enunciar porque retoma certos enunciados (com seus estilos próprios) e porque espera provocar respostas em certos gêneros, com suas peculiares estilísticas. Ou seja, o estilo só se constitui no dialogismo.

Dos três elementos do gênero - o conteúdo temático, a estrutura composicional e o estilo -, é o primeiro aquele que mais me interessa discutir neste artigo. Isso porque, creio, a redação do vestibular da Unicamp, que abordo neste texto, possui características que a tornam especialmente interessante para a análise do dialogismo no que toca ao conteúdo temático. Passemos, então, a uma concisa descrição das características da proposta de redação desse vestibular.

\section{A redação no vestibular da Unicamp: indicações das propostas e uso da coletânea}

Na proposta de redação do vestibular da Unicamp, o candidato pode escolher entre três gêneros: dissertação, narração e carta argumentativa. ${ }^{2}$ Para cada um desses gêneros, o candidato deve seguir a proposta de desenvolvimento temático indicada na prova. A análise das redações selecionadas como as melhores e publicadas pela Comvest (Comissão Permanente para os Vestibulares Unicamp) em coletâneas mostra que essas redações são uma espécie de "resposta" às propostas, na medida em que se percebe nitidamente nelas como os candidatos buscaram atender às indicações da prova. ${ }^{3} \mathrm{~A}$ proposta da redação é a palavra alheia que antecede o enunciado do candidato e à qual, por meio de sua redação, ele responde.

Além disso, o atendimento às indicações da prova mostra como todo enunciado se lança às avaliaçóes futuras. $\mathrm{O}$ candidato atende à proposta porque sabe que seu enunciado - sua redação - será avaliado. Se mesmo numa situação cotidiana da vida, por exemplo, quando falamos acerca do aumento do pão

\footnotetext{
${ }^{2}$ Para uma discussão mais completa sobre as propostas de redação do vestibular da Unicamp, indicamos nossa dissertação de Mestrado, "Gênero e estilo nas melhores redações do vestibular Unicamp” (MACIEL, 2008), realizada sob orientação da Prof ${ }^{a}$ Dr $^{\text {a }}$ Raquel Salek Fiad.

${ }^{3}$ Ver Maciel (2008).
} 
com nosso vizinho, queremos ser bem avaliados, aceitos, enfim, ainda mais importante é essa avaliação em um contexto de prova como o vestibular. Os candidatos guiam-se pelas instruções da prova de modo a conseguirem um bom julgamento de seus textos. A redação, assim, está nitidamente voltada à futura correção a que estarão submetidos.

Além disso, a redação no vestibular da Unicamp também é interessante para análise do dialogismo porque a coletânea simula uma dos fatores imprescindíveis da comunicação: o diálogo com vozes alheias. A coletânea no vestibular da Unicamp é um conjunto de textos e de excertos de textos, nos mais variados gêneros, que abordam de diferentes formas o tema sobre o qual o candidato deverá discorrer em sua redação.

$\mathrm{Na}$ vida, nossos enunciados são sempre baseados em enunciações prévias. Mesmo, por exemplo, uma conversa sobre a queda de temperatura em um determinado dia está saturada de enunciados precedentes. Podemos nos reportar às notícias veiculadas em jornais acerca dessa queda de temperatura, por exemplo. Também podemos retomar a fala de um conhecido que já nos adiantou que acreditava que neste dia as temperaturas estariam mais baixas. No caso da redação no vestibular, por meio da coletânea, o candidato tem a sua disposição uma série de enunciados que poderá retomar. Além disso, esses enunciados, em geral, apresentam grande gama de pontos de vistas, de forma que o enunciador poderá encontrar, na coletânea, enunciados com os quais concorda e outros de que discorda. Assim, como nós, que podemos acreditar no jornal, mas desconfiar de nosso conhecido.

Entretanto, algo notório divide nosso enunciado acerca da queda de temperatura e o enunciado do candidato em sua redação do vestibular. Enquanto podemos ocultar (deliberadamente ou não) nossas fontes, o candidato precisará, necessariamente, explicitar seu diálogo com a coletânea. Podemos omitir quem nos adiantou sobre as temperaturas mais baixas, além disso, também não seremos provavelmente indagados acerca das fontes (quais jornais) em que buscamos as informaçóes sobre esse fenômeno climático. Provavelmente porque, na comunicação cotidiana, pouco nos referimos às origens de nosso discurso, é que podemos acreditar que ele, nosso discurso atual, é nosso, como se não fosse parcialmente também dos enunciados alheios que o permeiam e que lhe dão forma. É pela dificuldade de buscarmos as origens, muitas vezes remotas, de nossas palavras, que até chegamos a imaginar que não haja palavras alheias em nossos enunciados. Exatamente porque, no vestibular, o uso da palavra do outro é explícito é que as redações são um 
material tão interessante para se observar o dialogismo. Ao ler uma redação e a coletânea que deu margem à sua formulação, podemos perceber claramente como as palavras alheias se tecem na voz do candidato. A coletânea, portanto, se ao vestibulando permite simular uma situação real de comunicação, por outro lado, permite-nos, como estudiosos da linguagem, observar o dialogismo de uma maneira mais clara, pois o diálogo com outras vozes é bastante nítido.

Desse modo, o atendimento às propostas da prova, o uso da coletânea e a influência da avaliação a que estão submetidas fazem das redações do vestibular da Unicamp um oportuno material para que se estude o dialogismo. A seguir, analiso uma redação a fim de tentar mostrar como o dialogismo se expressa neste texto.

\section{Um exemplo de dissertação: o trabalho humano visto de uma perspectiva menos otimista}

A seguir, são transcritas a proposta para dissertação do vestibular Unicamp de 2002 (COMVEST, 2002, p. 31-32) e, logo depois, uma redação (COMVEST, 2002, p. 53-57), eleita pela Comvest como uma das que melhor atenderam a essa proposta.

O trabalho humano tem assumido múltiplas dimensões ao longo da história. As alternativas que têm sido postas à disposição ou que têm sido negadas aos indivíduos ou à espécie permitem amplo leque de avaliaçôes. Encontra-se tanto uma defesa incondicional das virtudes da vida laboriosa quanto o elogio do ócio ou a defesa de um tempo de trabalho apenas indispensável à sobrevivência.

Levando em conta as pressóes históricas, sociais e mesmo psicológicas que condicionam estas visões, exemplificadas nos textos desta coletânea que permitem uma discussão da questão em seus aspectos contraditórios, escreva uma dissertação sobre o tema:

Trabalho: fator de promoção ou de degradação. 


\section{O trabalho: novo instrumento de degradação}

Fábulas, provérbios, ditos populares. "O trabalho dignifica o homem", "o trabalho liberta". A referência ao trabalho é constante na literatura e em outras formas de expressão ideológica. $\mathrm{O}$ trabalho e o homem parecem eternamente ligados. A caracterização de um período histórico, de um modo de produção, da estrutura e da conjuntura de dada época passam necessariamente pela caracterização do tipo de trabalho realizado no período, tanto em relação à sua forma de recompensa - salário, casa ou chibata - quanto em relação à sua produtividade e eficácia. Aparentemente, o homem sempre manteve relaçōes de trabalho. É essa expressão eternizada do trabalho que coíbe a reflexão quanto à validade do trabalho como atividade inerente ao homem.

Primitivamente, o trabalho apresentava-se como necessidade à sobrevivência e seu fruto era repartido coletivamente. $\mathrm{O}$ trabalho visto como atividade de mérito e remuneração individual, suprimindo qualquer ideário de comunidade e articulação social é criação recente. $O$ trabalho passou de necessidade imposta para sobrevivência natural a necessidade imposta para sobrevivência social. Com a detenção dos meios de produção por uma única classe - não interessada em qualquer ideia de coletividade primitiva - o trabalho tornou-se a única "propriedade" do proletariado, sua mercadoria para a nova sociedade de classes, sua arma de sobrevivência.

Mas a aceitação do trabalho como atividade digna não foi imediata principalmente na sociedade brasileira, onde quem trabalhava (escravos) estava no último degrau da classificação social, e a elite era composta justamente pelos adeptos do ócio (os grandes proprietários).

A visão negativa do trabalho, típica da sociedade brasileira prérepublicana, é um claro exemplo da influência estrutural e ideológica na formação de um conceito definido de trabalho (como degradante ou dignificante). Portanto, até mesmo a visão atual de trabalho como necessidade na formação moral do ser humano nada mais é do que uma adaptação ideológica a determinada estrutura econômica e social que tem no trabalho e na produção de excedentes sua base de sustentação.

Nesse contexto, o trabalho para produção de excedentes se tornou a única opção para inserção social. Dessa forma, o trabalho dignifica o homem, sim, não por sua essência bruta, mas por ser condição obrigatória à não marginalização. Trabalhar é manter-se vivo. Os desempregados exército de reserva ameaçador - servem como força externa para coerção do 
indivíduo a trabalhar cada vez mais, produzir o que não consome, receber cada vez menos, sujeitar-se ao "sistema".

E o homem, ex-sujeito da história, tornou-se objeto do sistema. A tecnologia, as máquinas e robôs seriam nossa salvação, enfim a liberdade do homem em relação ao trabalho. Ilusão. Tornaram-se apenas novas formas de coerção, instrumentos mais eficazes para mastigar a dignidade e reproduzir a miséria humana. Talvez o movimento ludista estivesse certo: a máquina é inimiga do homem; a máquina, expressão máxima do desenvolvimento técnico humano, potencializa a ambição, geradora da miséria humana.

O resultado da assimilação da tecnologia aos meios de produção ilustra a relação atual do homem com o trabalho. Ao invés de utilizar-se da técnica para libertar-se da obrigação do trabalho, o homem utilizou-a para implementar a produção. O trabalho tornou-se obrigatório e instrumento de opressão e distinção social. O homem não mais trabalha para si, tornouse escravo do trabalho, num ciclo de imposições sociais que mantém os trabalhadores, como gado, submissos à vontade do patrão. E esse, por sua vez, é uma marionete do sistema, do mercado, do monstro que o homem impôs a si mesmo: a ambição - a mesma que conduziu o conceito de trabalho de atividade dignificante para relação obrigatória e degradante.

Essa redação é apenas um exemplo de como a instrução da proposta direciona fortemente a escrita dos escreventes. ${ }^{4}$ Ao falar sobre o trabalho, muitos vestibulandos, atentos à proposta, trouxeram, em seus textos, visões negativas sobre o trabalho. Embora possa parecer trivial assumir que o trabalho encerra aspectos negativos, é preciso lembrar que, em nossa sociedade capitalista, em que, em geral, o trabalho é praticamente o único meio de vida digna, a ideologia dominante é a que defende aberta e ardorosamente o trabalho. Assim, supondo, por exemplo, que o tema fosse apenas "fale sobre

\footnotetext{
${ }^{4}$ Outro exemplo da influência das instruções pode ser visto em nossa dissertação de mestrado (MACIEL, 2008, p. 76), em que analisamos os textos dos candidatos que responderam ao vestibular de 2003. Embora a proposta para escrita de uma carta argumentativa trouxesse aos candidatos a possibilidade de serem favoráveis ou contrários à tese do articulista Rosenfield, que tem um artigo reproduzido na coletânea, todos os candidatos foram contrários ao articulista. Ao que nos parece, essa opção unânime decorre da própria proposta da prova, que trazia elementos que serviam de auxílio para se combater a tese do articulista.
} 
o trabalho", parece plausível imaginar que haveria uma acentuada glorificação da vida laboriosa, inclusive com críticas ao ócio (preguiça), sendo raras as menções aos aspectos negativos do trabalho. É o contrário disso, porém, que se encontra na maior parte das redaçóes selecionadas para comporem a coletânea das melhores redações do vestibular Unicamp. ${ }^{5}$ Em todas essas redações há opiniōes contrárias à glorificação do trabalho.

A redação transcrita anteriormente é um exemplo de como as instruções do tema direcionam (e é exatamente isso que é esperado e cobrado) a realização dos textos dos candidatos. A começar pelo título "O trabalho: novo instrumento de degradação", vê-se o diálogo da redação com a proposta, cujo tema é "Trabalho: fator de promoção ou de degradação". Basta observar, por exemplo, que, se a proposta tratasse do trabalho apenas como fator de promoção, seria incoerente o título ir precisamente contra essa perspectiva, contemplando as dimensões negativas do trabalho. A própria discussão, elaborada ao longo de todo o texto, sobre trabalho como uma atividade muitas vezes degradante claramente é uma "resposta" à proposta.

Atendendo ao que é colocado para elaboração da redação, o candidato já traz, no primeiro parágrafo, o debate sobre a "validade do trabalho como atividade inerente ao homem", relativizando, desde o início de seu texto, essa "validade". Em sua "reflexão quanto à validade do trabalho", o candidato abordará diferentes visóes sobre o trabalho: desde sua glorificação até à necessidade do ócio. Isso mostra que, considerando a proposta da prova, ele passa pelas diferentes "alternativas que têm sido postas à disposição ou que têm sido negadas" aos trabalhadores.

O candidato segue descrevendo que:

(...) primitivamente, o trabalho apresentava-se como necessidade à sobrevivência e seu fruto era repartido coletivamente. $\mathrm{O}$ trabalho visto como atividade de mérito e remuneração individual, suprimindo qualquer ideário de comunidade e articulação social é criação recente. O trabalho passou de necessidade imposta para sobrevivência natural a necessidade imposta para sobrevivência social.

Neste ponto, o candidato parece dialogar com a afirmação da proposta de que o "trabalho humano tem assumido múltiplas dimensões ao longo da história”. Em seu texto, exemplifica como o trabalho pôde assumir diferentes

${ }^{5}$ Ver Maciel (2008). 
dimensōes durante o decorrer histórico, como atesta a mudança na forma de se ver o trabalho: antes como atividade comunitária para sobrevivência e atualmente como atividade individual e meritória.

Continuando em seu panorama histórico, afirma que o trabalho deixa de ser uma atividade coletiva e representa, agora, apenas um instrumento de avaliação social, por meio do qual aqueles que trabalham são vistos como mais "dignos". Entretanto, o candidato fará uma ressalva quanto a essa suposta dignidade associada ao trabalho. Segundo ele, "a aceitação do trabalho como atividade digna não foi imediata - principalmente na sociedade brasileira, onde quem trabalhava (escravos) estava no último degrau da classificação social, e a elite era composta justamente pelos adeptos do ócio (os grandes proprietários)". Essa ressalva certamente vai ao encontro da solicitação da prova de que na "discussão da questão [do trabalho] em seus aspectos contraditórios", leve-se "em conta as pressōes históricas, sociais e mesmo psicológicas que condicionam estas visões [acerca do trabalho]". Por esse exemplo de como o trabalho era mal visto na sociedade brasileira escravista, no período pré-republicano, o candidato mostra como "as pressōes históricas" influenciam marcadamente as "visões" sobre o trabalho: visto como indigno no passado, atualmente é fator de reconhecimento social.

Atento, portanto, as "alternativas que têm sido postas à disposição ou que têm sido negadas aos indivíduos ou à espécie", o candidato atesta que, hodiernamente, o trabalho é a única alternativa para a "não marginalização". No bojo da discussão primordial da proposta sobre o discernimento do trabalho como "fator de promoção ou de degradação", o vestibulando afirma que:

(...) o trabalho dignifica o homem, sim, não por sua essência bruta, mas por ser condição obrigatória à não marginalização. Trabalhar é manterse vivo. Os desempregados - exército de reserva ameaçador - servem como força externa para coerção do indivíduo a trabalhar cada vez mais, produzir o que não consome, receber cada vez menos, sujeitar-se ao "sistema".

Ou seja, em sua concepção, o trabalho não é uma opção, mas uma imposição, e seu caráter, portanto, não é de uma atividade dignificante; pelo contrário, é degradante. Desse modo, o autor responde explicitamente à proposta e marca que, entre os dois modos de conceber o trabalho - como dignificante ou como degradante-, é este último que impera no cenário atual, pois a ambição "conduziu o conceito de trabalho de atividade dignificante para relação obrigatória e degradante". 
Por meio da paráfrase do texto do candidato, retomando, a título de análise comparativa, a proposta, é possível notar como as indicações da prova ecoam em sua dissertação. No desenvolvimento de seu texto, o vestibulando, embasado pela proposta, discorreu sobre o tema, atendendo de perto às exigências da prova. Sua escrita é uma "resposta" àquilo que é colocado na proposta da prova: cada indicação da proposta é extremamente importante na confecção de seu texto, cada indicação é criteriosamente respondida por ele. Sua redação, assim, é um claro exemplo do dialogismo constitutivo da linguagem; ela dialoga com a proposta, um enunciado precedente, ao qual "responde".

Seguindo as instruçôes, o candidato cumpre, muito satisfatoriamente, aquilo que lhe foi sugerido na proposta. Entretanto, mesmo assim, poderia ter sua redação anulada, caso não atendesse a uma imprescindível exigência da prova, a de que, em sua discussão, deveria buscar referências sobre o trabalho que são "exemplificadas nos textos dessa coletânea [do vestibular]" ${ }^{6}$ Por isso, além do diálogo com a proposta, o texto traz vários elementos da coletânea, o que nos possibilita observar a relação do candidato com vozes de "outros".

$\mathrm{O}$ autor abre seu texto citando vozes alheias que já falaram sobre o trabalho. Aliás, essas diversas vozes falaram sobre esse tema em diferentes gêneros: "Fábulas, provérbios, ditos populares". Agora, cabe ao candidato, em seu enunciado, do gênero redação do vestibular - se assim podemos chamálo - abordar esse mesmo objeto. Em enunciados alheios, em gêneros outros, o candidato pode buscar as vozes com as quais dialogará em seu texto. Isso demonstra que, ao enunciar sobre um tema, podemos buscar vozes que tenham falado sobre ele em gêneros diferentes daqueles em que concretizamos nossa enunciação.

Nos "ditos populares" é que o candidato elege a primeira voz claramente alheia que trará para seu enunciado, valendo-se do conhecido provérbio popular "O trabalho dignifica o homem". Na coletânea esse provérbio aparece parodiado por Maguila, ex-lutador de boxe, como "o trabalho danifica o homem"; entretanto não é ao provérbio parodiado que recorre o candidato, mas ao provérbio original, já que ele procura ilustrar com esse provérbio qual é acepção mais comum sobre o trabalho, ou seja, como algo que dignifica. A visão mais comum é a que assevera que o trabalho "liberta", como atesta a referência que o candidato faz ao excerto três da coletânea, em que se lê: "3. Arbeit macht frei ('o trabalho liberta', divisa encontrada nos portōes do campo de concentração de Auschiwitz)" (COMVEST, 2002, p. 33).

${ }^{6}$ Para acesso à coletânea completa desse vestibular, ver Maciel (2008), p. 156-160. 
Esses dois pontos de vista, o de que o trabalho liberta, bem como o de que o trabalho dignifica (ambos se aproximam por sua visão positiva do trabalho) serão refutados pelo autor. Para ele, o trabalho tem, sim, aspectos positivos, mas também tem seus pontos negativos, muitas vezes esquecidos. Retomando a palavra alheia para contrapor-se a ela, o candidato demonstra que sabe utilizar a coletânea a partir de seu projeto discursivo, valendo-se, inclusive, da palavra do outro para negá-la. Ele se aproveita da voz do outro, insere-a em seu enunciado, mas nega essa voz. Isso é um exemplo claro de como se dá a comunicação humana, pois nos valemos dos enunciados alheios, inúmeras vezes, com o objetivo de negá-los. Na dissertação do candidato, a voz do outro, da qual discorda, está a serviço de seu projeto discursivo, sendo contestada, pois, para o candidato, o trabalho não é necessariamente bom, nem sempre "liberta".

O autor segue, em seu texto, comparando os modos pelos quais o trabalho pôde ser visto ao longo do tempo, expondo como o valor do trabalho mudou com o transcorrer dos anos. Segundo ele, primitivamente, "o trabalho apresentava-se como necessidade à sobrevivência e seu fruto era repartido coletivamente", enquanto, atualmente, com "a detenção dos meios de produção por uma única classe (...), o trabalho tornou-se a única 'propriedade' do proletariado, sua mercadoria para a nova sociedade de classes, sua arma de sobrevivência”. Essa comparação, entre duas formas de se ver o trabalho, parece trazer à dissertação ideias expressas por Pierre Clastres no fragmento de seu texto "A sociedade contra o Estado", reproduzido na coletânea. Para Clastres, no "mundo primitivo" havia ausência de uma "força externa" que obrigasse os homens a trabalharem "além de suas necessidades". O candidato aproveita essa ideia e sugere que a força externa, no mundo atual, éa "detenção dos meios de produção por uma única classe", que obriga o homem ao trabalho, pois essa é sua única "arma de sobrevivência".

Criticando ainda a atual acepção do trabalho "como necessidade na formação moral do ser humano", o vestibulando lembrará que essa visão "nada mais é do que uma adaptação ideológica a determinada estrutura econômica e social". Confirmação de que se trata tão somente de uma "adaptação ideológica" e não de algo realmente inerente ao trabalho é o exemplo trazido em sua dissertação de que "a aceitação do trabalho como atividade digna não foi imediata - principalmente na sociedade brasileira, onde quem trabalhava (escravos) estava no último degrau da classificação social, e a elite era composta justamente pelos adeptos do ócio (os grandes fazendeiros)". Se a coletânea não 
traz nenhuma referência acerca do trabalho escravo no Brasil, isso não nos impede de ver nesse exemplo histórico o diálogo do candidato com outras vozes - no caso, enunciados alheios que não estão presentes na coletânea. $\mathrm{O}$ exemplo histórico confirma que apenas o infindável diálogo pode manter viva a memória de um povo, transmitindo (e recontando) de voz em voz um fato do passado.

Seguindo em sua retrospectiva histórica, o candidato declara ter sido ilusão acreditar que "a tecnologia, as máquinas e robôs seriam a nossa salvação, enfim a liberdade do homem em relação ao trabalho". Para o vestibulando, talvez "o movimento ludista estivesse certo: a máquina é inimiga do homem; a máquina, expressão máxima do desenvolvimento técnico humano, potencializa a ambição, geradora da miséria humana”. Aqui, a referência ao movimento ludista, mostra, mais uma vez, que o candidato dialoga com outras vozes, além daquelas expressas na coletânea, já que nesta não há menção alguma às lutas de Ned Ludd e seus companheiros contra as máquinas. Como já dito anteriormente em relação à retomada das informações históricas do período escravista no Brasil, ao se valer de fatos históricos para desenvolver sua tese, o texto do candidato nos exemplifica como as informações de momentos passados podem ser retomadas por vozes atuais. É pela contínua retomada de enunciados precedentes que a história pode manter-se através do diálogo infinito das vozes.

Nesse diálogo, entra também a voz do candidato, materializada em sua redação no vestibular. Pela análise de seu texto, procurei mostrar como qualquer enunciado está sempre e necessariamente prenhe de enunciados precedentes. Evidência disso são os excertos da coletânea retomados pelo candidato, bem como o recurso a exemplos históricos, que denotam como as informações do passado passam - e se mantêm - através do fluxo contínuo do dialogismo.

Além disso, ao vermos como o candidato segue cuidadosamente as indicaçóes da proposta sobre o desenvolvimento do tema, podemos perceber como os enunciados se voltam às respostas futuras. No caso da redação do vestibular, a resposta esperada pelo candidato é sua nota e não realmente uma resposta, como num diálogo cotidiano. Exatamente por ser uma situação de avaliação é que o vestibular se torna mais interessante para observar a expectativa da recepção que todo falante tem ao enunciar. Em toda comunicação humana, sempre nos dirigimos a alguém e esperamos sua avaliação acerca do que enunciamos. No caso da redação do vestibular, esse 
aspecto da futura avaliação a que nossos enunciados estão sujeitos é ainda mais claro, porque o candidato precisa, para ser bem avaliado, seguir as instruções da proposta.

A redação, portanto, como diria Bakhtin ([1952-1953], p. 289), é mais um "elo na cadeia da comunicação discursiva", retomando a coletânea e seguindo as indicações da prova, visando a uma, futura, avaliação. Sua redação é um exemplo de como um enunciado se constitui no diálogo com vozes precedentes e futuras.

Hoje nós também retomamos àquela redação, escrita em novembro de 2001, a fim de, agora, esmiuçá-la, analisá-la, e nosso texto, este presente artigo, também poderá ser, no futuro, retomado, respondido, constituindo-se em mais uma voz que integra o infindável diálogo.

\section{Considerações finais}

Em nossa exposição pretendemos exemplificar, por meio da análise de uma redação, como um enunciado real mantém vínculos dialógicos. A escolha pela redação de exame de vestibular se deve ao fato de que esses vínculos são, neste caso, mais evidentes, pois a situação discursiva assim o exige: o candidato deve responder à proposta da prova e trazer, para seu texto, enunciados alheios que compóem a coletânea do exame vestibular.

Se, em toda enunciação, o falante se preocupa com o julgamento de seu interlocutor, mais ainda no contexto da prova de vestibular, em que o vestibulando sabe que, para ser bem avaliado, precisa seguir atentamente as indicações da prova. Ou seja, o candidato está consciente de quanto sua redação deve responder adequadamente à proposta de escrita a que está submetido. Ilustra isso o fato de que, em sua redação, o autor se coloque contrariamente à glorificação da vida laboriosa. Ao que nos parece, esse posicionamento se deve bastante à proposta da prova que, indo além do senso comum de exaltação do trabalho, apontava para a degradação a que o trabalho pode conduzir o ser humano.

Explicitam também o caráter dialógico dos enunciados, os elos que a redação mantém com enunciados precedentes. Em seu texto, o vestibulando se vale de várias vozes alheias: algumas derivadas da coletânea de textos, outras oriundas de seu conhecimento prévio. Utilizando essas vozes para dar vida ao texto, o candidato emprega-as a favor de seu projeto discursivo. Assim, conjuga tanto enunciados alheios com os quais concorda quanto enunciados alheios de que discorda, usando aqueles para reforçar sua tese e esses para criticá-los. 
Nosso estudo dessa redação, portanto, teve o intuito de explicitar como as condiçóes específicas da prova do vestibular da Unicamp favorecem a observação do dialogismo que perpassa todas as enunciaçōes humanas.

Encerramos, na esperança de que também nossa análise se constitua em mais um elo na comunicação discursiva. Como personagem do cenário linguístico atual, nossa reflexão traz em sua voz ecos do passado, pois parte de discussões teóricas bastante difundidas atualmente no Brasil, e se lança a respostas futuras, trazendo a análise dessa redação para a apreciação dos interlocutores que dela se ocuparem.

\section{Referências}

BAKHTIN, M. M. (1924). O problema do conteúdo, do material e da forma na criação literária. In: BAKHTIN, M. M. Questôes de literatura e de estética: a teoria do romance. 3. ed. Trad. Aurora Fornoni Bernardini et al. São Paulo: Unesp; Hucitec, 1993. p. 13-70.

. (1929/1963). Problemas da poética de Dostoiévski. 2. ed. revista. Trad. Paulo Bezerra. Rio de Janeiro: Forense Universitária, 1997. 379 p.

. (1934-1935). O discurso no romance. In: BAKHTIN, M. M. Questôes de literatura e de estética: a teoria do romance. 3. ed. Trad. Aurora Fornoni Bernardini et al. São Paulo: Unesp; Hucitec, 1993. p. 71-210.

. [1952-1953]. Os gêneros do discurso. In: In: BAKHTIN, M. M. Estética da criação verbal. 4. ed. Trad. Paulo Bezerra. São Paulo: Martins Fontes, 2003. p. 261-306.

BAKHTIN, M. M./ VOLOSHINOV, V. N. (1929). Marxismo e filosofia da linguagem. 12. ed. Trad. Michel Lahud \& Yara Frateschi Vieira. São Paulo: Hucitec, 2006. 203 p.

COMVEST. Redações do Vestibular Unicamp 2002. Pró-Reitoria de Graduação, Comissão Permanente para os vestibulares, Pró-Reitoria de Extensão e Assuntos Comunitários. Campinas: Editora da Unicamp, 2002. 250 p.

MACIEL, L. V. C. Gênero e estilo nas melhores redaçôes do vestibular Unicamp. 2008. 185 p. Dissertação (Mestrado em Linguística Aplicada) - Instituto de Estudos da Linguagem, Universidade Estadual de Campinas, Campinas, 2008. VOLOSHINOV, V. N. (1930). La structure de l'énoncé. In: TODOROV, T. (Org.). Mikhail Bakhtine: le principe dialogique. Paris: Éditions du Seuil, 1981. p. 287-316.

Recebido em 03/02/09. Aprovado em 30/06/09. 